\title{
Sistem Customer Relationship Management untuk Perusahaan Penjualan Alat Komputer Menggunakan Analisis Fishbone
}

\author{
Nur Fajriati Yuniar ${ }^{*}$, Inge Handriani ${ }^{2}$ \\ 1,2Program Studi Sistem Informasi, Universitas Mercu Buana, Jakarta Barat, DKI Jakarta \\ Email: ${ }^{1 *}$ nfyuniar@gmail.com, ${ }^{2}$ inge.handriani@mercubuana.ac.id
}

(Naskah masuk: 25 Sep 2020, direvisi: 12 Okt 2020, diterima: 14 Okt 2020)

\begin{abstract}
Abstrak
Pelayanan kepada pelanggan merupakan salah satu faktor yang mendasari pelanggan dalam membeli produk. Pelayanan yang baik akan memberikan kepuasan kepada pelanggan. Kepuasan pelanggan dapat menjadi penentu dalam kegiatan bisnis. Pada beberapa perusahaan masih memiliki masalah berkaitan dengan pelayanan kepada pelanggan, dimana pengolahan data yang belum terintegrasi dan tidak adanya sistem yang membantu pelanggan untuk berkomunikasi dengan pihak perusahaan. Sehingga menyulitkan pelanggan ketika ingin mengetahui progress pesanannya, maupun saat akan mengajukan layanan purna jual. Hal ini dapat menurunkan loyalitas pelanggan terhadap perusahaan yang dapat mengakibatkan berpindahnya pelanggan pada pesaing. Solusi yang diberikan dalam hal ini adalah perlunya sebuah konsep sistem Customer Relationship Management, yang akan menyediakan pelayanan terhadap kebutuhan pelanggan. Tujuannya adalah untuk menjaga hubungan perusahaan dengan pelanggan dan meningkatkan loyalitas pelanggan pada perusahaan. Analisis sistem yang digunakan dalam menemukan kebutuhan sistem berkaitan dengan pelayanan terhadap pelanggan adalah dengan menggunakan metode analisis Fishbone. Konsep sistem ini menghasilkan informasi pelayanan atas order penjualan, purna jual, pembaharuan data produk, dan informasi piutang pelanggan.
\end{abstract}

Kata Kunci: Customer Relationship Management, Pelayanan, Fishbone, Prototype.

\section{Customer Relationship Management System for Computer Equipment Sales Company Using Fishbone Analysis}

\begin{abstract}
Customer service is one of the factors that underlie customers in purchasing products. A good service gives customer satisfaction. Customer satisfaction can be determinant in business activities. Some companies still have problems relating to customer service, which is data processing has not been integrated, and no system that helps customers communicate with the company. So it's difficult for a customer to monitor his order progress, or for requesting after-sales service. It can reduce the customer's loyalty to the company that can make the customers turn to the competitors. The solution given in this case is its need for a concept of a customer relationship management system, which would provide service to the needs of customers. Its goal is to maintain company relations with the customers and increase customer loyalty to the company. The system analysis used in finding system needs related to customer service is by using the fishbone analysis. The concept of this system produces service information on sales orders, after-sales service, product updates, and account receivable.
\end{abstract}

Keywords: Customer Relationship Management, Service, Fishbone, Prototype

\section{PENDAHULUAN}

Perusahaan harus menyadari bahwa keputusan pelanggan dalam membeli produk tidak hanya didasarkan oleh kualitas produk dan harga, namun juga kualitas pelayanan. Pelayanan yang bermutu tinggi berarti mampu memberikan kesesuaian terhadap kebutuhan pelanggan. Kepuasan pelanggan dapat 
meningkat jika harapan pelanggan terpenuhi. Begitu pula sebaliknya, kepuasan pelanggan dapat menurun jika harapan pelanggan tidak terpenuhi [1]. Kepuasan pelanggan dapat menjadi penentu dalam kegiatan bisnis. Pelanggan akan lebih memilih untuk membeli produk kepada perusahaan yang sudah terjamin kepuasannya [2]. Oleh karena itu, menciptakan nilai lebih bagi pelanggan sangat penting karena mengarah pada pembelian berulang yang menguntungkan bisnis [3]. Banyak perusahaan yang berusaha untuk memberikan pelayanan terbaik bagi pelanggannya dengan melakukan kerja sama dengan pihak luar yang lebih kompeten agar pekerjaan menjadi lebih efisien dan efektif. Pelayanan yang baik akan memberikan kepuasan kepada pelanggan [4]. Pelayanan kepada pelanggan merupakan tanggung jawab semua bagian. Kualitas produk yang dijanjikan seorang sales kepada pelanggan bergantung pada kemampuan bagian produksi. Begitu pula bagian pengiriman, bagian ini memerlukan informasi dari seorang sales mengenai pengiriman barang sehingga mereka bisa mengatur pengiriman sesuai dengan kesepakatan antara penjual dan pembeli.

Seiring dengan berkembangnya teknologi informasi, pelanggan lebih mudah dalam mencari barang atau jasa yang diinginkan. Banyak penjual mulai melakukan pemasaran menggunakan internet. Dengan menggunakan internet, biaya pemasaran yang dikeluarkan tidak terlalu besar namun dapat menjangkau pelanggan ke berbagai tempat dalam waktu yang singkat [5]. Dengan adanya internet, pelanggan dapat membandingkan beberapa penjual dengan mudah tanpa harus datang ke toko. Hal ini dapat menurunkan loyalitas pelanggan kepada perusahaan langganannya. Hal serupa juga disampaikan pada penelitian lainnya bahwa loyalitas pelanggan menunjukkan penurunan karena kemudahan dalam mencari barang dan jasa yang dapat ditemukan melalui teknologi media sosial [6]. Pemasaran melalui media sosial menempati urutan teratas di antara teknik pemasaran digital [7]. Media sosial merupakan media online yang dapat digunakan semua orang untuk berbagi cerita dan berkomunikasi. Media sosial adalah sebuah media online yang dapat digunakan untuk berbagi, dan membuat cerita melalui blog, jejaring sosial, dan forum [8]. Adanya media sosial, pelanggan lebih mudah mengungkapkan rasa kecewanya kepada penjual yang dapat dilihat oleh pelanggan lain maupun calon pelanggan, sehingga dapat memperburuk citra perusahaan [2].

Untuk mempertahankan loyalitas pelanggan kepada perusahaan, beberapa perusahaan mulai mementingkan kepuasan pelanggan. Beberapa hal yang dilakukan perusahaan untuk memuaskan hati pelanggan yaitu dengan merespon permintaan pelanggan dan mempermudah pelanggan dalam bertransaksi dengan perusahaan. Salah satu cara memuaskan hati pelanggan yaitu dengan memahami keinginan pelanggan, memudahkan akses pelanggan, serta merespon kebutuhan pelanggan dengan cepat dan tepat [9]. Solusi yang diberikan adalah perlunya sebuah konsep sistem Customer Relationship Management, yang akan menyediakan pelayanan terhadap kebutuhan pelanggan. Customer Relationship Management merupakan sistem informasi yang digunakan untuk mengendalikan keseluruhan aktivitas penjualan dalam suatu perusahaan. Customer Relationship Management merupakan gabungan antara pemasaran, penjualan, dan kebijakan pelayanan yang digunakan agar seluruh aktiitas antar divisi dapat terkoordinasi [6][10]. Customer Relationship Management adalah usaha perusahaan untuk meningkatkan nilai bagi pelanggan dengan menghubungkan proses dan fungsi internal perusahaan dengan jaringan eksternal perusahaan sehingga menciptakan profit bagi perusahaan [11]. Tujuan dibuatnya sistem informasi ini adalah untuk membantu perusahaan dalam menjaga hubungan dengan pelanggan dan meningkatkan kesetiaan pelanggan pada perusahaan. Penerapan E-CRM yang telah dilakukan memudahkan pihak salon dalam mengelola dan memberikan pelayanan kepada pelanggan, sehingga dapat meningkatkan loyalitas pelanggan yang sudah ada dan berpeluang lebih besar untuk memperoleh pelanggan baru [12]. Dengan adanya CRM pelanggan lebih mudah untuk berkomunikasi dengan perusahaan sehingga kepuasan pelanggan dapat meningkat [13]. Apabila perusahaan mengimplementasi CRM, maka perusahaan dapat membuat hubungan yang lebih intens dengan pelanggan, dan perusahaan dapat melihat pelanggan mana yang lebih aktif pembeliannya serta mengkalkulasi pendapatan yang diperoleh dari hubungannya dengan pelanggan [14]. Melalui CRM diharapkan data dan informasi yang akan dikumpulkan dapat berguna untuk pengambilan keputusan selanjutnya [15]. Penelitian ini hanya berfokus pada proses penjualan peralatan komputer dan proses pelayanan purna jual, mulai dari perancangan sistem produk, perancangan sistem penjualan, perancangan sistem pelayanan purna jual, dan perancangan sistem pengecekan account receivable. Konsep CRM ini merupakan hal pertama yang akan diterapkan pada perusahaan Smartindo Integrasi System.

\section{METODE PENELITIAN}

Penelitian ini mengambil sumber data dengan menggunakan metode field research pada perusahaan dagang yang menjual peralatan komputer. Data yang dikumpulkan pada perusahaan tersebut dilakukan analisis dengan menggunakan metode kualitatif. Hasil penelitian ini dipaparkan di dalam laporan dengan menggunakan metode deskriptif.

Untuk menyempurnakan penelitian ini, dilakukan pengumpulan data dengan teknik observasi pada proses penawaran barang, penginputan penjualan, pembuatan surat jalan, dan proses purna jual. Kemudian melakukan wawancara ke beberapa staf penjualan, staf pengiriman, staf bagian invoice, staf gudang, staf helpdesk, staf product manager, dan staf finance. Pada penelitian ini juga mendapatkan data dokumen sebagai acuan proses bisnis yang terjadi dalam bentuk kertas form pendaftaran pelanggan baru, price list, surat jalan, tanda terima servis, juga invoice dan faktur pajak.

Untuk memperjelas tahapan penelitian yang dilakukan dapat terlihat setiap tahapannya pada bagan dibawah ini: 


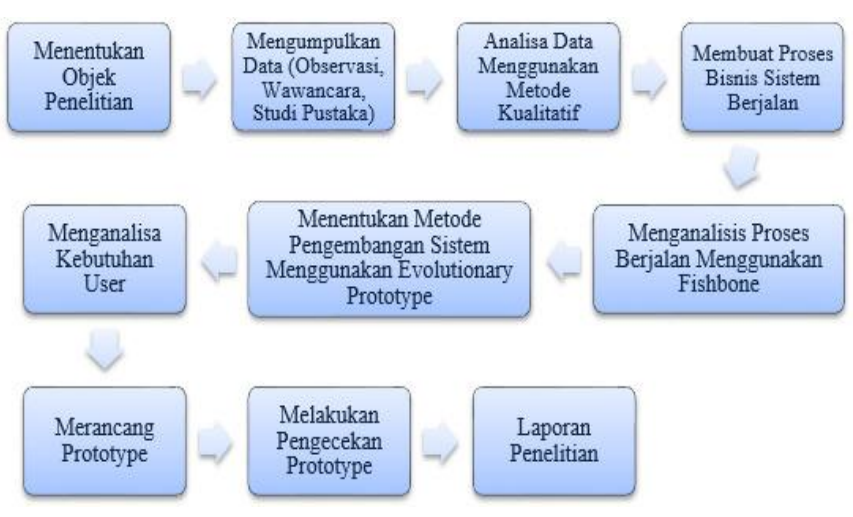

Gambar 1. Alur Tahapan Penelitian

Adapun penjelasan diagram alir penelitian yang dilakukan yaitu sebagai berikut:

1. Menentukan Objek Penelitian

Objek penelitian merupakan sesuatu yang menjadi perhatian dalam suatu penelitian, objek penelitian ini menjadi sasaran dalam penelitian untuk mendapatkan jawaban ataupun solusi dari permasalahan yang terjadi.

2. Pengumpulan Data

Pengumpulan data dilakukan dengan teknik observasi, wawancara, dan studi pustaka. Teknik observasi dilakukan pada proses penawaran barang, penginputan penjualan, pembuatan surat jalan, dan proses purna jual. Kemudian melakukan wawancara ke beberapa staf penjualan, staf pengiriman, staf bagian invoice, staf gudang, staf helpdesk, staf finance, dan staf product manager. Pada penelitian ini juga mendapatkan data dokumen sebagai acuan proses bisnis yang terjadi dalam bentuk kertas form pendaftaran pelanggan baru, price list, surat jalan, tanda terima servis, juga invoice, dan faktur pajak.

3. Analisis Data Menggunakan Metode Kualitatif

Setelah mendapatkan data dari proses pengumpulan data, data dianalisis sehingga menjadi data yang memiliki makna.

4. Membuat Proses Bisnis Sistem Berjalan

Setelah melihat langsung proses bisnis yang terjadi di lapangan, maka dibuatlah proses bisnis sitem berjalan.

5. Menganalisa Proses Menggunakan Fishbone

Proses analisis dilakukan untuk mengidentifikasi masalahmasalah yang terjadi pada proses berjalan.

6. Menentukan Metode Pengembangan Sistem

Setelah diketahui masalah yang dihadapi pada proses berjalan, dibutuhkan metode pengembangan yang dapat menghasilkan solusi dari permasalahan yang terjadi, metode yang digunakan yaitu Evolutionary Prototype.

7. Menganalisa Kebutuhan User

Pada tahap ini dilakukan pengumpulan kebutuhan dari sistem dengan cara mendengar keluhan dari pengguna agar sistem sesuai dengan kebutuhan.
8. Merancang Prototype

Pada tahapan ini, dilakukan perancangan prototype. Prototype yang dibuat disesuaikan dengan kebutuhan sistem yang telah didefinisikan sebelumnya dari keluhan pengguna.

9. Melakukan Pengecekan Prototype

Prototype dari sistem di cek oleh pengguna. Lalu dilakukan evaluasi kekurangan-kekurangan dari kebutuhan pengguna

\section{HASIL DAN PEMBAHASAN}

A. Proses Bisnis Berjalan

Berdasarkan pengumpulan data yang dilakukan dapat membantu dalam menganalisa permasalahan yang ada dan menentukan strategi yang terbaik untuk mengembangkan sistem. Proses bisnis berjalan dapat dilihat pada Gambar 2 .

Gambar 2 merupakan proses bisnis yang sedang berjalan saat ini. Tahapan pertama yaitu pelanggan meminta penawaran kepada sales melalui telepon, Whatsapp, atau email. Setelah itu sales memberikan penawaran sesuai dengan permintaan pelanggan. Apabila pelanggan ingin membeli barang yang ditawarkan, maka pelanggan harus mengirimkan Purchase Order kepada sales. Setelah Purchase Order diterima, sales mengecek apakah pelanggan tersebut merupakan pelanggan baru atau tidak. Jika pelanggan tersebut merupakan pelanggan baru, sales harus meminta data lengkap pelanggan dengan memberikan form pelanggan baru, lalu menginputkan data pelanggan ke dalam Sales Order. Namun seringkali sales melewatkan tahapan untuk mengirimkan form pelanggan baru kepada pelanggan baru. Setelah data pelanggan terinput di dalam Sales Order, sales menginputkan data penjualan ke dalam Sales Order. Setelah data penjualan terinput, finance akan mengecek piutang pelanggan dan mempertimbangkan untuk mengizinkan atau menolak penjualan tersebut. Setelah finance mengizinkan penjualan tersebut, maka gudang dapat menyiapkan barang dan menginputkan Serial Number Unit. Kemudian admin membuatkan surat jalan lalu diberikan kepada tim gudang untuk dilakukan quality control dan dikirim. Setelah barang terkirim, surat jalan yang telah ditandatangani pelanggan diberikan kepada admin invoice untuk dibuatkan invoice dan faktur pajaknya.

\section{B. Hasil Analisis Fishbone}

Pada tahap ini dilakukan analisis sistem dengan menggunakan metode Fishbone. Hal ini bertujuan untuk mengetahui permasalahan yang terjadi dan sebab akibatnya. Selanjutnya untuk menentukan kebutuhan sistem apa yang mampu membantu menyelesaikan permasalahan yang ada. Analisa fishbone dapat dilihat pada Gambar 3. 


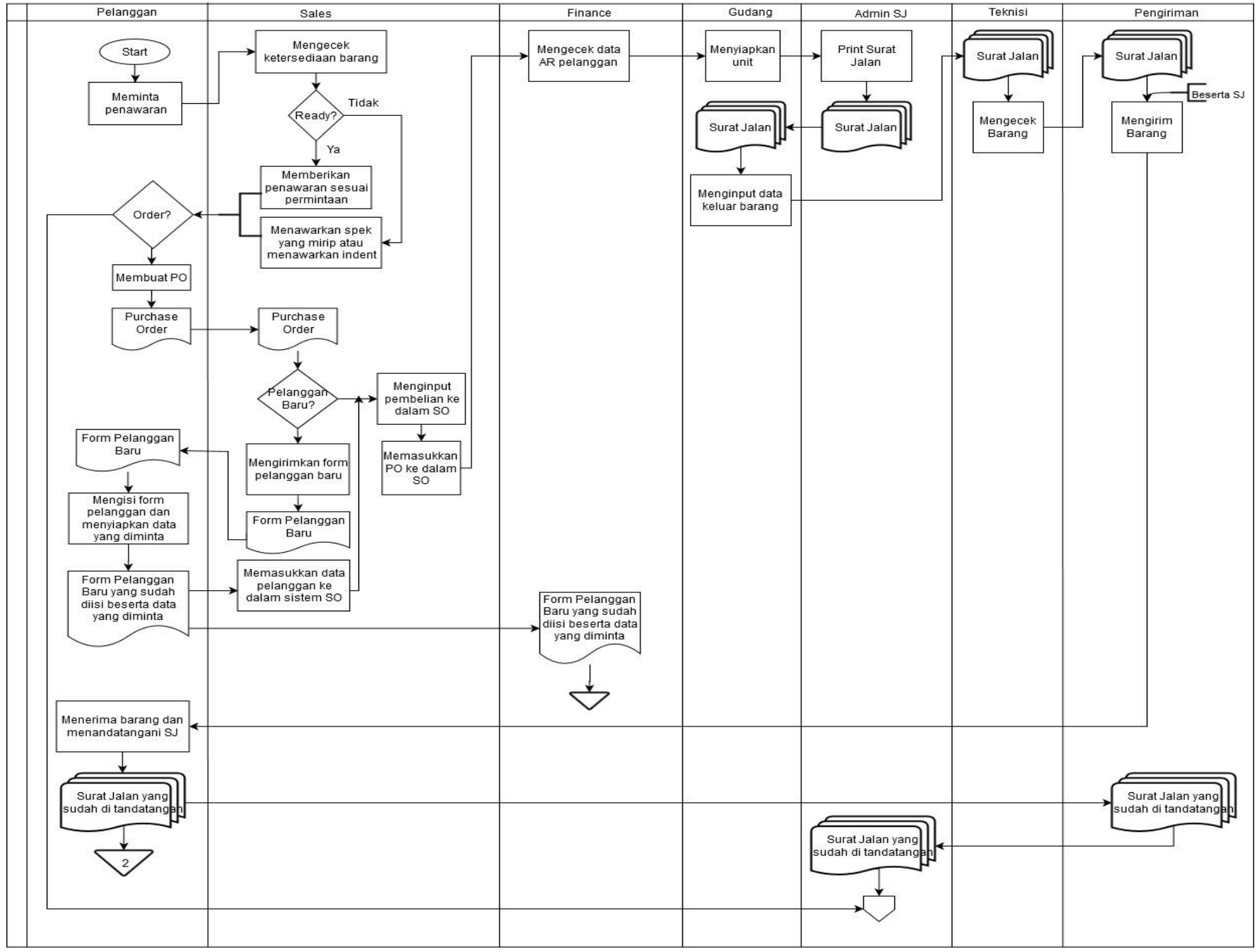

Gambar 2. Proses Bisnis Berjalan

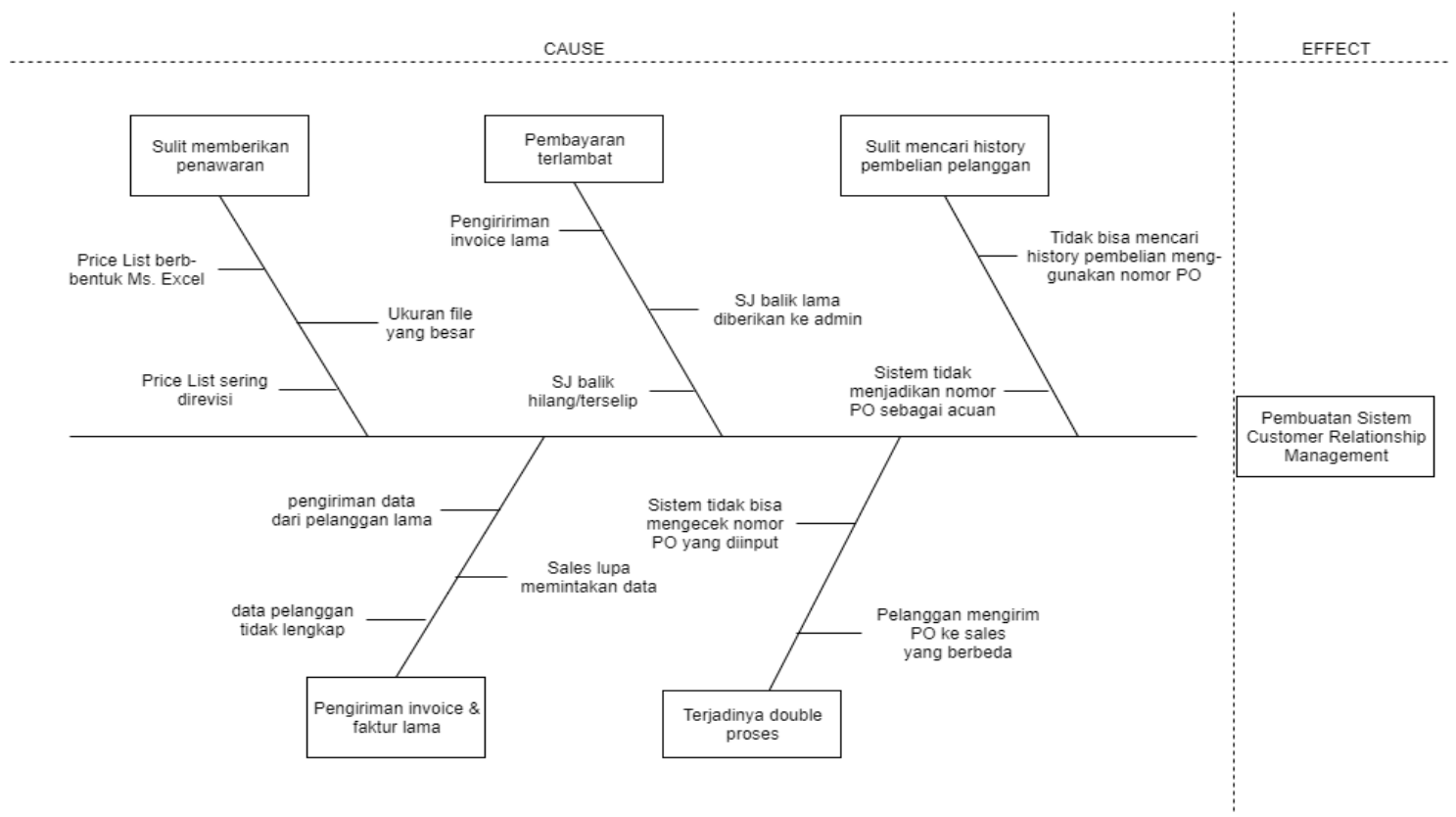

Gambar 3. Analisis Fishbone 
Gambar 3 merupakan analisis Fishbone. Setelah dianalisis, ditemukan beberapa masalah seperti:

1. Sulit memberikan penawaran

- Dalam hal ini sulit memberikan penawaran yang dimaksud adalah ketika sales tidak berada di meja kerjanya. Biasanya pelanggan meminta penawaran lewat telepon, Whatsapp, atau email.

- Hal ini disebabkan karena price list yang digunakan berbentuk Microsoft Excel dan memiliki ukuran yang lumayan besar, sehingga ada beberapa sales yang tidak menyimpan price list tersebut di dalam smartphone-nya. Selain ukuran yang besar, sales merasa tidak leluasa saat membuka file price list di dalam smartphone-nya.

- Solusinya adalah membuatkan akses kepada sales dan pelanggan untuk melihat price list kapanpun dan dimanapun sehingga sales tidak perlu menyimpan file besar di dalam smartphone-nya, dan pelanggan tidak perlu menanyakan spesifikasi produk kepada sales.

2. Lamanya pengiriman invoice dan faktur pajak pelanggan.

- Pengiriman invoice dan faktur pajak yang dimaksud adalah pengiriman kepada pelanggan baru. Untuk pelanggan baru diharuskan memberikan data lengkap perusahaan sebelum memulai transaksi.

- Penyebab dari pengiriman yang lama yaitu karena data pelanggan yang dimiliki perusahaan kurang lengkap. Terkadang sales lupa memintakan data lengkap kepada pelanggan baru. Dan setelah diminta, pelanggan terkadang lama memberikan data tersebut.

- Hal ini dapat diatasi dengan mengharuskan sales untuk meminta data lengkap pelanggan sebelum pembeliannya diproses. Sebelum datanya lengkap, sales tidak bisa menginput data pelanggan baru ke dalam sistem sehingga sales tidak bisa menginput pembelian pelanggan ke dalam sistem.

3. Pembayaran terlambat.

- Yang dimaksud pembayaran terlambat adalah ketika piutang pelanggan dibayarkan lebih dari periode waktu yang diberikan perusahaan.

- Hal ini disebabkan surat jalan yang telah ditandatangani pembeli lama dikembalikan ke admin, bahkan ada yang hilang maupun terselip dan tidak ada yang mengetahui. Hal tersebut dapat memperlambat pengiriman invoice kepada pelanggan sehingga dapat memperlambat pembayaran.

- Solusinya adalah membuat monitoring surat jalan yang sedang dikirim. Ketika kurir mengirim barang pesanan pelanggan, kepala pengiriman akan update pembelian tersebut menjadi dikirim didalam sistem. Ketika data di update menjadi dikirim, maka data tersebut akan masuk ke dalam halaman 'Terkirim', sehingga bagian pengiriman maupun admin mengetahui surat jalan mana saja yang sedang dikirim, dan bisa dicek apakah surat jalan tersebut kembali ke admin atau tidak. Ketika barang diterima oleh pelanggan akan melakukan konfirmasi penerimaan barang. Dan ketika surat jalan sudah diterima admin akan melakukan 'Final Check' yang artinya Surat Jalan sudah diterima oleh admin, dan data tersebut akan masuk ke halaman 'History'.

4. Terjadinya dobel proses.

- Dobel proses artinya 1 nomor Purchase Order pelanggan diproses dua kali.

- Biasanya hal ini disebabkan karena pelanggan mengirimkan Purchase Order ke sales yang berbeda, atau sales yang sama tidak mengingat kalau Purchase Order tersebut sudah pernah diproses sebelumnya. Sistem tidak dapat mengecek apakah nomor Purchase Order tersebut pernah diproses atau tidak, dan bagian admin juga tidak mengecek nomor Purchase Order setiap pembelian, sehingga beberapa kali terjadi dobel proses.

- Hal ini bisa diatasi dengan melakukan pengecekan nomor Purchase Order sebelum di input. Ketika sales memasukkan Purchase Order pelanggan ke dalam sistem, sales diminta untuk memasukkan nomor Purchase Order tersebut. Sales harus klik tombol cek terlebih dahulu. Ketika di klik, sistem akan mengecek nomor Purchase Order tersebut apakah sudah pernah diinput atau belum. Jika pernah, sistem akan menampilkan nomor Sales Order dengan nomor Purchase Order yang sama.

5. Sulit mencari riwayat pembelian pelanggan

- Hal yang dimaksud disini adalah sulit mencari riwayat pembelian pelanggan berdasarkan nomor Purchase Order.

- Sistem tidak menjadikan nomor Purchase Order sebagai acuan dalam mencari riwayat pembelian pelanggan sehingga ketika sales ingin mengetahui riwayat pembelian berdasarkan nomor Purchase Order, sales harus mengecek satu-persatu.

- Solusinya adalah menyediakan fungsi pencarian berdasarkan nomor Purchase Order. Ketika ingin mencari riwayat pembelian pelanggan menggunakan nomor Purchase Order, sales tinggal klik tombol History, lalu pilih 'Purchase Order' sebagai jenis pencarian, lalu masukkan nomor Purchase Order yang ingin dicari.

\section{Use Case Diagram}

Use Case Diagram memperlihatkan gambaran dari sistem. Pada use case sistem Customer Relationship Management terdapat delapan actor. Berikut use case diagram yang diusulkan terlihat pada Gambar 4.

Gambar 4 merupakan gambar rancangan use case diagram usulan. Pada rancangan use case diagram ada delapan aktor yang diusulkan yaitu sales, pelanggan, finance, gudang, admin pengiriman, admin invoice, helpdesk, dan product manager. 


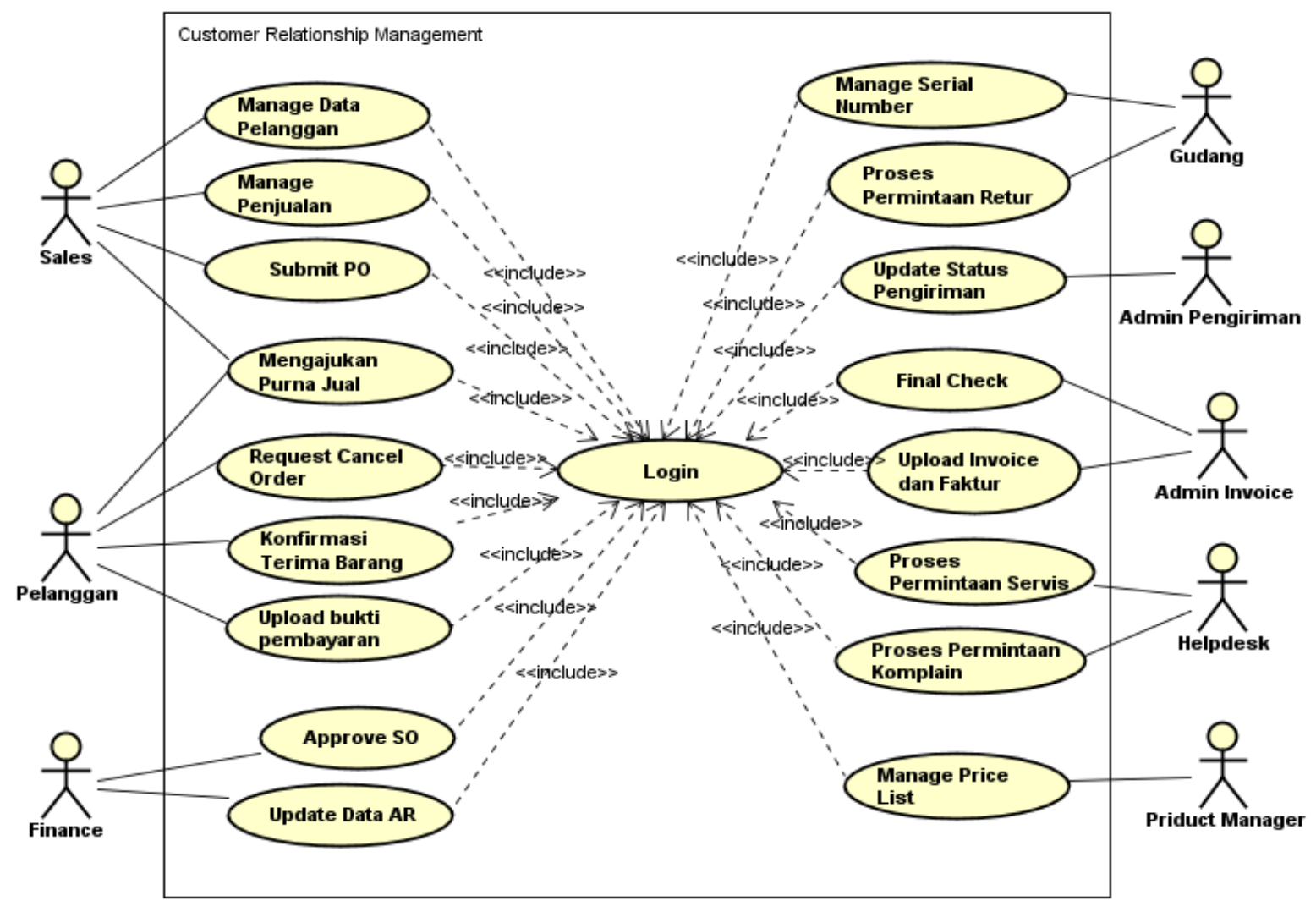

Gambar 4. Use Case Diagram Usulan

Berikut penjelasan masing-masing aktor.

1. Sales

Sales merupakan aktor dapat menginput serta merubah data pelanggan dan data penjualan. Sales juga dapat membantu pelanggan dalam mengajukan purna jual.

2. Pelanggan

Pelanggan merupakan aktor yang dapat melihat data pembeliannya dan mengajukan layanan purna jual.

3. Finance

Finance merupakan aktor yang dapat approve penjualan serta mengupdate data pembayaran.

4. Gudang

Gudang merupakan aktor yang dapat menginput serial number unit serta memproses permintaan return barang.

5. Admin Pengiriman

Admin pengiriman merupakan aktor yang dapat mengupdate pengiriman barang pelanggan.

6. Admin Invoice

Admin invoice merupakan aktor yang dapat klik final check setelah barang terkirim kepada pelanggan. Apabila sudah final check artinya barang tersebut sudah diterima pelanggan dan surat jalan telah kembali kepada admin.

7. Helpdesk

Helpdesk merupakan aktor yang dapat memproses permintaan servis dan komplain.

8. Product Manager

Product manager merupakan aktor yang dapat menginput serta merubah data produk
D. Proses Bisnis Customer Relationship Management

Proses bisnis yang diusulkan pada penelitian ini dibagi menjadi 3 bagian, yaitu pre-transaction, during-transaction, dan post-transaction. Pre-transaction berisi proses-proses yang terjadi sebelum adanya transaksi, seperti pendaftaran pelanggan. Pelanggan tidak dapat mendaftarkan dirinya sendiri, namun yang mendaftarkannya adalah sales. Sales harus mengisi data lengkap pelanggan sesuai dengan form yang ada pada sistem. Setelah data pelanggan terdaftar, sales dapat memberikan username dan password kepada pelanggan sehingga pelanggan dapat login ke dalam sistem. Proses pretransaction dapat dilihat pada Gambar 5.

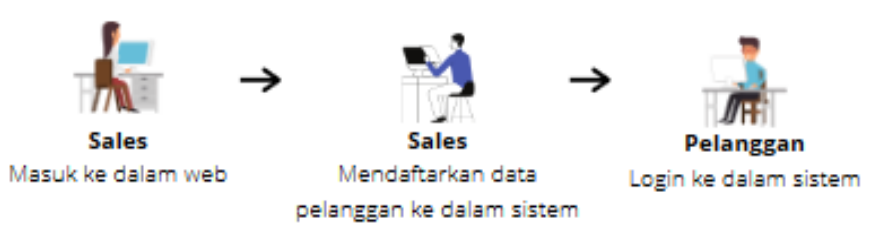

Gambar 5. Proses Pre-Transaction

Proses yang kedua yaitu during-transaction. During transaction berisi proses-proses yang terjadi selama transaksi berlangsung. Hal pertama yang harus dilakukan ketika pelanggan ingin membeli produk yaitu pelanggan mengirimkan purchase order kepada sales. Setelah itu, sales akan mengecek dan menginput data penjualan ke dalam sistem. Setelah data penjualan terinput, finance akan 
mengecek AR dan approve penjualan tersebut. Setelah itu gudang akan memasukkan serial number unit ke dalam sistem, lalu admin akan membuat surat jalan. Setelahnya teknisi akan mengecek unit dan membawanya ke bagian pengiriman. Ketika barang sedang dikirim, admin pengiriman akan update status penjualan. Surat jalan yang telah ditandatangani pelanggan diberikan kepada admin invoice untuk dibuatkan invoice dan faktur pajak. Setelah pelanggan membayar tagihan, finance akan update status penjualan menjadi paid yang artinya telah terbayar. Proses duringtransaction dapat dilihat pada Gambar 6

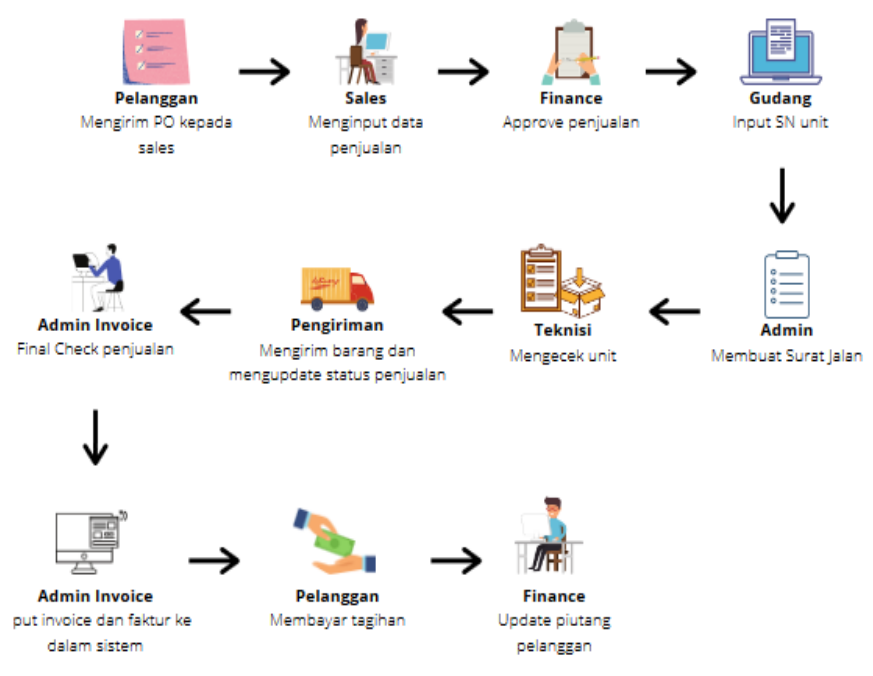

Gambar 6. Proses During-Transaction

Proses yang ketiga yaitu post-transaction. Posttransaction berisi proses-proses yang harus dilakukan ketika pelanggan ingin mengajukan purna jual. Hal pertama yang harus dilakukan ketika pelanggan ingin mengajukan purna jual adalah mencari data pembeliannya. Setelah itu pelanggan dapat klik Ajukan Purna Jual dan mengisi data pengajuan purna jualnya. Setelah data terinput, gudang akan mendapatkan notifikasi apabila ada pengajuan untuk return barang, sedangkan pengajuan komplain maupun servis akan masuk ke notifikasi helpdesk. Setelah itu, gudang maupun helpdesk dapat memproses dan mengupdate pengajuan purna jual. Proses post-transaction dapat dilihat pada Gambar 7.

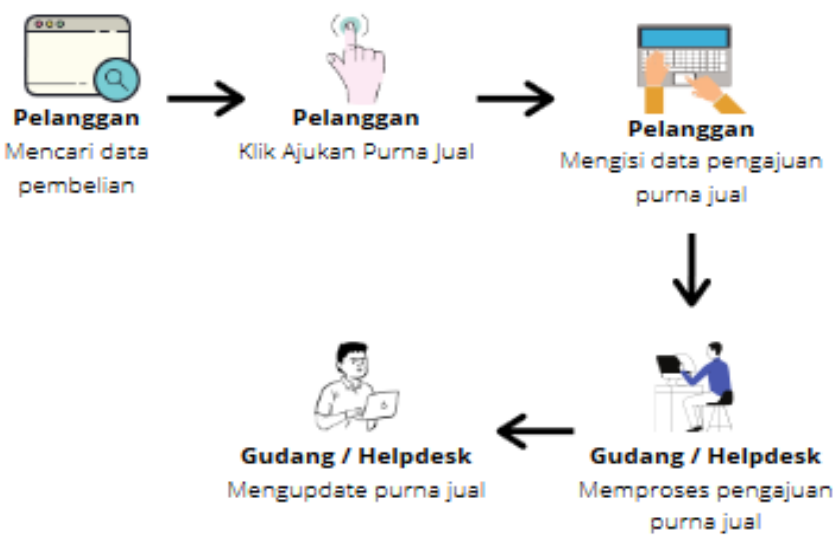

Gambar 7. Proses Post-Transaction

\section{E. Class Diagram}

Pada penelitian ini menggunakan class diagram sebagai media untuk menggambarkan struktur sistem yang terdapat pada sistem ini, dapat dilihat pada Gambar 8 .
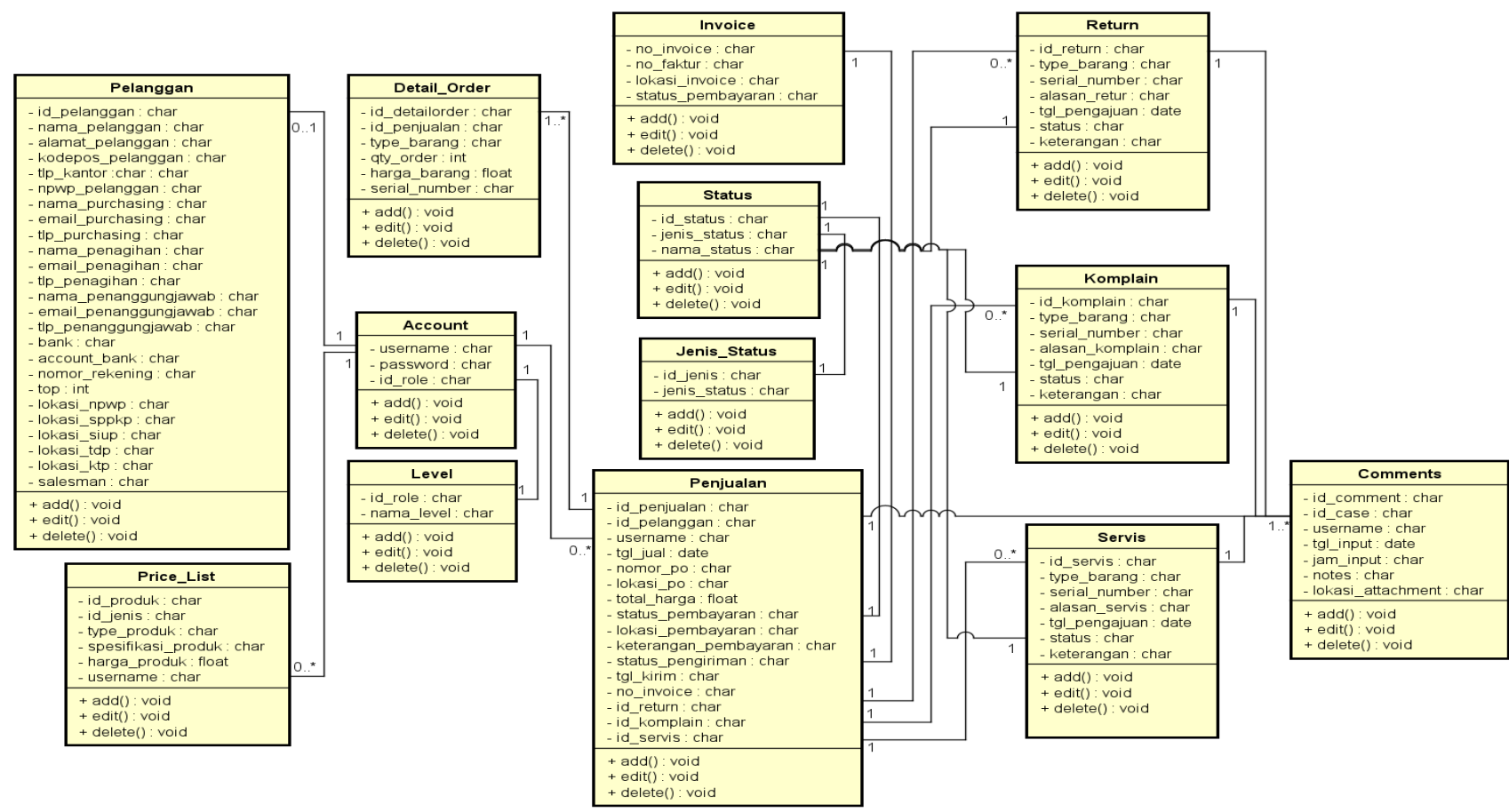

Gambar 8. Class Diagram Usulan 


\section{F. Design Interface}

\begin{tabular}{|c|c|c|c|c|c|}
\hline \multicolumn{5}{|c|}{$\diamond \Leftrightarrow x \Leftrightarrow \overrightarrow{\text { hitp: }: l}$} & \\
\hline \multicolumn{5}{|l|}{ Smartindo } & (Q) Username \\
\hline \multirow{2}{*}{\begin{tabular}{|l} 
Price List \\
Order
\end{tabular}} & & & & & \begin{tabular}{|l|} 
Downlood Price List \\
\end{tabular} \\
\hline & Product ID & Type & Specification & Dealer Price & Suggested \\
\hline \begin{tabular}{|l|} 
History \\
Woitno Poyment
\end{tabular} & $\mathrm{V} 3468-\mathrm{i} 3$ & \begin{tabular}{|l} 
Dell Vostro \\
348
\end{tabular} & 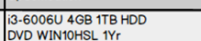 & Rp 3000.000 & Rp 4.000.000 \\
\hline \begin{tabular}{|l|} 
Komplain \\
\end{tabular} & V3468-i5 & $\begin{array}{l}\text { Dell Vostro } \\
3468\end{array}$ & $\begin{array}{l}5-750004 \text { GB } 1 \text { TB HDD } \\
\text { DVD WIN1OHSL 1Yr }\end{array}$ & $R p 5000.000$ & Rp 60000.000 \\
\hline Servis & v5490.17 & $\begin{array}{l}\text { Dell Vostro } \\
3468\end{array}$ & $\begin{array}{l}\text { 7.-10510U 8GB 512GB } \\
\text { MX250 208 WINIOPRO TYR }\end{array}$ & Rp7 7800.000 & RP85000.000 \\
\hline \multirow[t]{5}{*}{ Retur } & XPS15.7590 & \begin{tabular}{|l|l|l|l|l|l|} 
Dell XPS \\
157590
\end{tabular} & 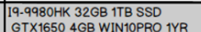 & $R p 50.00 .000$ & Rp53.000000 \\
\hline & XPS13.7390 & $\begin{array}{l}\text { Dell XPS } \\
137390\end{array}$ & $\begin{array}{l}\text { 17.1065G6 16G6 } 51208 \\
\text { WIN10PRO IYR }\end{array}$ & RP39.800000 & $R p 42.000 .000$ \\
\hline & N3481-i3 & $\begin{array}{l}\text { Dell Inspiron } \\
3481\end{array}$ & $\begin{array}{l}133.70200 \text { 4GB ITB } \\
\text { WIN1OHSL TYR }\end{array}$ & $R p 6.500 .000$ & $R_{p} 7.900 .000$ \\
\hline & N3493-i5 & \begin{tabular}{|l|l|l|l|l} 
\\
Dell Inspiron \\
3493
\end{tabular} & $\begin{array}{l}\text { 5-1035G1 4GB 1TBMX } 230 \text { 2GB } \\
\text { WIN10HSL IYR }\end{array}$ & $R_{p} 98000.000$ & Rp 10.700 .000 \\
\hline & \multicolumn{5}{|c|}{ NABPCALLCD } \\
\hline
\end{tabular}

Gambar 9. Rancangan UI Halaman Price List

Gambar 9 di atas merupakan gambar rancangan user interface price list untuk pelanggan. Pada halaman ini pelanggan dapat melihat produk apa saja yang ada beserta spesifikasinya. Pelanggan juga dapat melihat harga pasaran untuk dealer dan user. Pada price list ini dibedakan berdasarkan jenis nya, yaitu notebook (NB), personal computer (PC), dan monitor (LCD). Harga yang tertera masih bisa dinegosiasikan kepada sales sehingga harga yang diinput ke dalam penjualan tidak selalu sama. Pada desain ini membuat sales dan pelanggan dapat melihat price list kapanpun dan dimanapun.

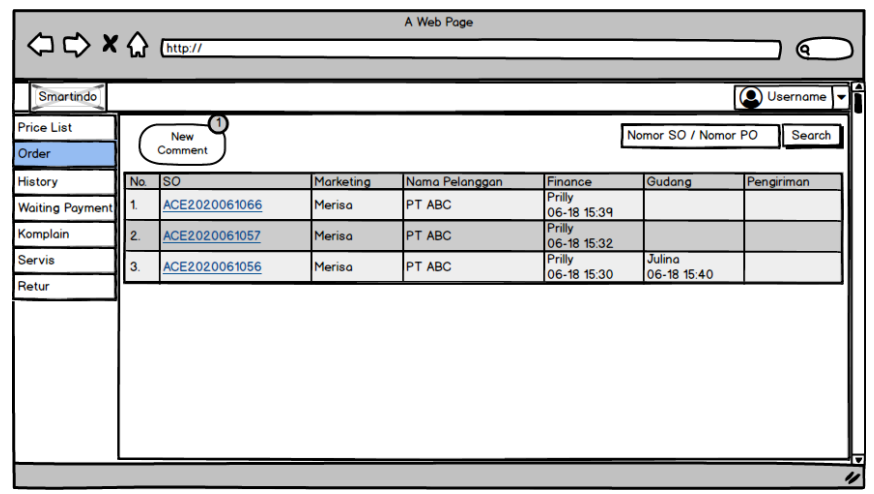

Gambar 10. Rancangan UI Order

Gambar 10 di atas merupakan gambar rancangan user interface Order. Pada halaman ini pelanggan dapat melihat semua pembelian yang sedang diproses. Pelanggan dapat melihat sejauh mana proses pembeliannya. Pelanggan juga dapat mencari pembelian dengan menginputkan nomor sales order atau nomor Purchase Order pada bagian search order. Untuk melihat detail pembelian nya pelanggan dapat klik nomor sales order yang ada pada tampilan di atas. Untuk pembelian yang sudah selesai akan hilang pada menu ini dan tetap bisa dilihat pada menu history. Untuk pembelian yang belum terbayarkan dapat dilihat pada menu Waiting Payment. Dengan mengetahui proses pembelian nya, pelanggan dapat melihat apakah terdapat kendala pada pembeliannya sehingga pelanggan dapat segera memutuskan hal apa yang akan dilakukan selanjutnya.

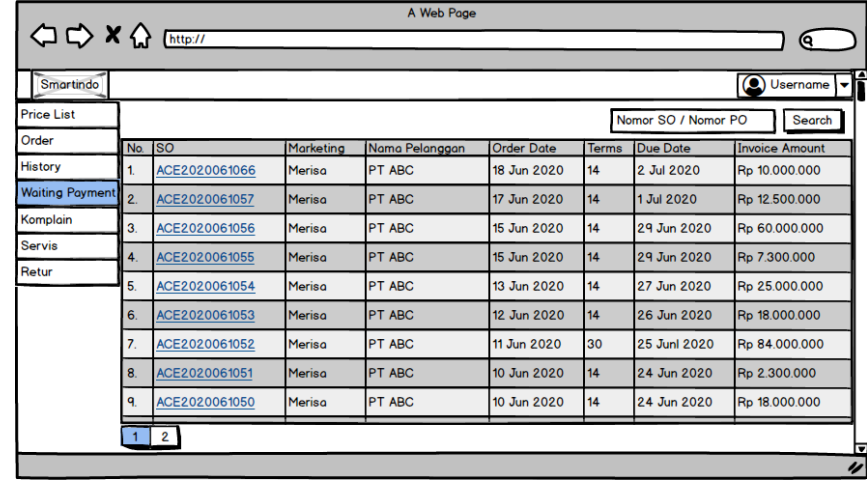

Gambar 11. Rancangan UI Waiting Payment

Gambar 11 di atas merupakan gambar rancangan user interface Waiting Payment. Halaman ini menampilkan pembelian pelanggan yang belum dibayarkan. Data yang tampil pada halaman ini yaitu nomor sales order, nama sales, nama pelanggan, tanggal pembelian, term of payment, due date pembayaran, dan total harga pembelian. Untuk melihat detail pembelian, pelanggan dapat klik nomor sales order yang ada pada tampilan di atas.

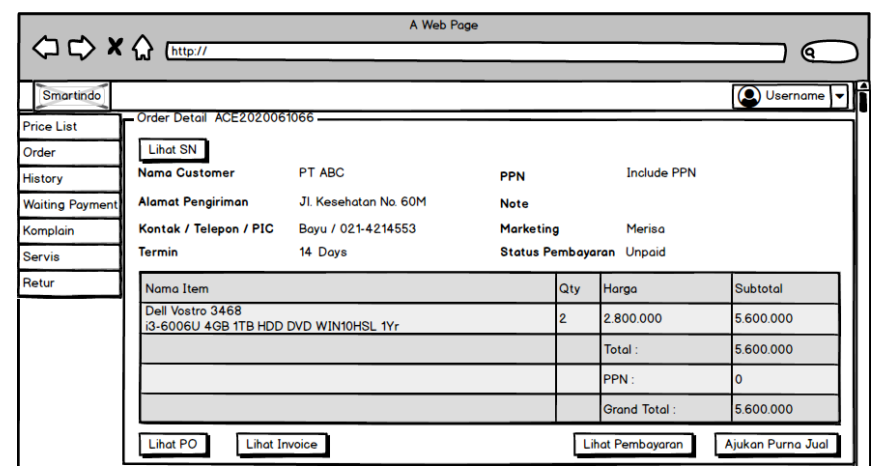

Gambar 12. Rancangan UI Detail Order

Gambar 12 di atas merupakan gambar rancangan user interface detail order untuk pembelian yang sudah selesai. Pada halaman ini pelanggan dapat melihat barang yang di order, nama sales yang memproses pembeliannya, status pembayaran, serial number unit, purchase order, invoice, dan faktur pajak. Pelanggan juga dapat upload pembayaran dan mengajukan purna jual.

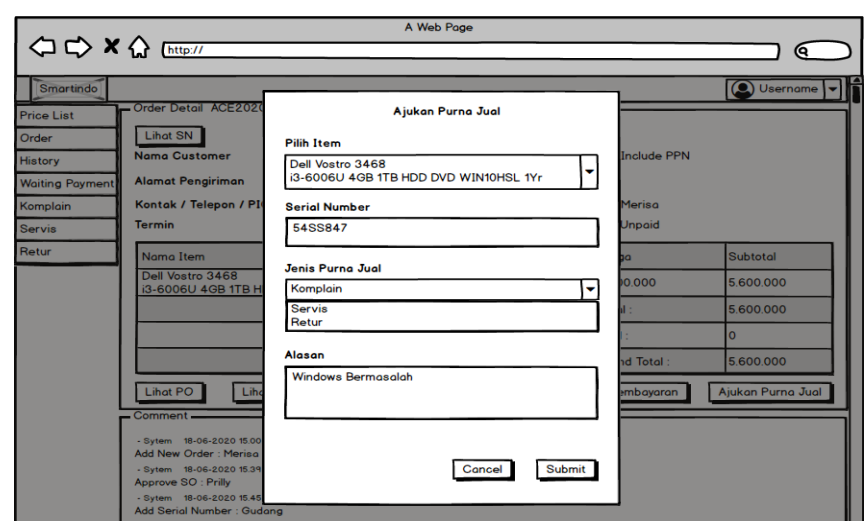

Gambar 13. Rancangan UI Mengajukan Purna Jual 
Gambar 13 merupakan rancangan user interface mengajukan purna jual. Pelanggan dapat mengajukan return, komplain, dan servis. Hal yang harus dilakukan untuk mengajukan purna jual ialah mencari data pembeliannya dan klik Ajukan Purna Jual pada detail pembelian. Setelah itu pelanggan dapat memilih item yang ingin diajukan purna jualnya, memasukkan serial number unit, memilih jenis purna jual, dan alasan mengapa mengajukan purna jual.

Gudang akan menerima notifikasi apabila terdapat pengajuan return barang. Sedangkan helpdesk akan menerima notifikasi apabila terdapat pengajuan komplain dan servis. Setelah pengajuan purna jual di submit, gudang maupun helpdesk dapat menerima maupun menolak pengajuan tersebut dan memberikan alasan maupun keterangan tambahan. Setelah pengajuan diproses maka status purna jual akan berubah. Apabila gudang maupun helpdesk menerima permintaan purna jual, ketika proses selesai gudang maupun helpdesk harus mengupdate purna jual tersebut menjadi selesai dengan cara klik Finish dan memberikan keterangan tambahan.

\section{KESIMPULAN}

Berdasarkan penelitian ini, dapat disimpulkan bahwa dalam perancangan aplikasi ini data produk dapat dimasukkan ke dalam sistem, sehingga sales maupun pelanggan dapat melihat produk terupdate. Pelanggan dapat memantau langsung status pesanan dan permintaan purna jualnya. Pelanggan dapat meminta layanan purna jual di dalam sistem sehingga pelanggan dapat mengetahui proses dari permintaan nya. Dokumen penjualan dan resi pengiriman dokumen tersebut dapat di input ke dalam sistem. Tagihan pelanggan dapat di update langsung di dalam sistem sehingga memudahkan finance dan pelanggan.

\section{REFERENSI}

[1] Jumaryadi, Y. (2019). Customer Complaint Information Systems at National Standardization. International Journal Information System and Computer Science (IJISCS), Vol. 3(2), pp. 43-49.

[2] Fauzi, A. \& Harli, E. (2017). Peningkatan Kualitas Pelayanan Melalui CRM Dengan Metode RAD. Jurnal RESTI (Rekayasa Sistem Dan Teknologi Informasi), Vol. 1(1), 76. DOI: 10.29207/Resti.V1i1.16

[3] Mang'unyi, E.E. Khabala, O. T., \& Govender, K. K. (2017). The Relationship Between E-CRM And Customer Loyalty: A Kenyan Commercial Bank Case Study. Banks and Bank Systems, Vol. 12(2), pp. 106115. DOI: 10.21511/Bbs.12(2).2017.11

[4] Rahayu, F. \& Irawan, H. (2019). Perancangan Sistem Electronic Customer Relationship Management (ECRM) Guna Membantu Meningkatkan Pelayanan Dan
Loyalitas Pelanggan Studi Kasus: Lembaga Pendidikan Kumon. Idealis, Vol. 2(4), pp. 205-212.

[5] Dewi, N. \& Warmika, I. (2017). Pengaruh Internet Marketing, Brand Awareness, dan Wom Communication Terhadap Keputusan Pembelian Produk Spa Bali Alus. E-Jurnal Manajemen Universitas Udayana, Vol. 6(10), pp. 5580-5606.

[6] Zakaria, H. \& Marlia, A. E. (2019). Perancangan Sistem Informasi Customer Relationship Management (CRM) Untuk Meningkatkan Loyalitas dan Pelayanan Customers Berbasis Web Dengan Model Waterfall. Jurnal Teknologi Sistem Informasi Dan Aplikasi, Vol. 2(2), 66-72. DOI: 10.32493/Jtsi.V2i2.2804

[7] Stojiljković, A. (2019). The Impact of Social Media Marketing on Customer Relationship Development. Journal of Process Management. New Technologies, Vol. 7(4), pp. 41-48. DOI: 10.5937/Jouproman7-22586

[8] Cahyono, A. S. (2016). Pengaruh Media Sosial Terhadap Perubahan Sosial Masyarakat Di Indonesia. Jurnal Ilmu Sosial \& Ilmu Politik Diterbitkan Oleh Fakultas Ilmu Sosial \& Politik, Universitas Tulungagung, Vol. 9(1), pp. 140-157.

[9] Somya, R. \& Utama, S.C. (2019). Perancangan Customer Relationship Management Berbasis Web Dengan Library Jquery Responsive Datatables. Jurnal Sistem Informasi, Vol. 8(3), 529-542.

[10] Widiana, W., Buana, P.W. \& Bayupati, I.P.A. (2020). Pemodelan Dan Implementasi Proses Bisnis Berbasis ECRM Menggunakan Aplikasi Vtiger CRM. Rekayasa Sistem Dan Teknologi Informasi, Vol 4(3), pp. 418-428.

[11] Fransisca, Imelda, \& Dafid. (2017). Sistem Informasi Manajemen Hubungan Pelanggan Pada PT. XYZ Palembang. Jurnal TAM (Technology Acceptance Model), Vol 8(1), pp. 1-7.

[12] Anisa, N., Yuliazmi \& Gata, G. (2020). Penerapan ECRM Pada Usaha Salon Dalam Meningkatkan Loyalitas dan Pelayanan Terhadap Pelanggan. Rekayasa Sistem Dan Teknologi Informasi, 4(2), pp. 268-275.

[13] Utomo, Y.B., Winarno, W.W. \& Amborowati, A. (2016). Perancangan Customer Relationship Management Pada Klinik (Studi Kasus: Klinik Pratama Nusa Medika Meritjan). Multitek Indonesia, Vol. 10(1), 57. DOI: 10.24269/Mtkind.V10i1.239

[14] Parulian, D. (2017). Pengembangan Sistem Customer Relationship Management (CRM) Menggunakan Metode IT Balanced Scorecard. Faktor Exacta, Vol. 10(3), pp. 278-287.

[15] Noorhansyah, M. \& Pratomo, A. (2016). Penerapan Model Customer Relationship Management pada Metodologi FAST (Studi Kasus: Pengembangan Portal Akademik Jurusan Administrasi Bisnis Politeknik Negeri Banjarmasin). Jurnal POSITIF, Vol. I(2), pp. 25-32. 